\title{
Macrolinguistic Complex Systems in Zimbabwean Political News Reports: A Systemic Analysis
}

\author{
Otto Tendayi Mponda * \\ (University of the Western Cape, United Kingdom)
}

\begin{abstract}
This study investigated the ideological use of linguistics features in online news articles published by The Zimbabwe Herald Online newspaper and The Zimbabwean Independent Online newspaper. The data was gathered during the period between 2008 and 2016 where there was media hype regarding the Zimbabwean political and economic instability. During this period in question Zimbabwe has had a constant phase of bad political and economic instability. Therefore, this publication is very crucial as it comes at a moment when Zimbabwe is undergoing its worst political and economic phase in years. Even though Zimbabwe's political situation seems to be unstable, the current government is adamant that the situation will get better before its its next presidential election in 2018. In 2009 the two political parties Zanu- PF and MDC forged a Unity Government, the end of the unity- government triggered power struggles within both Zanu- PF and MDC, which made Zimbabwean politics even more complicated. Consequently, the current study made use of thirty editorial articles ranging between 900 tokens to 1200 tokens. All the files gathered were transferred into text files so that they could be easily transferable into Antconc 3.2.1, which is a concordance software programme used in corpus linguistics to analyze written corpora. The lexical features that were identified in the study were analyzed through the use of Fairclough's (1989) Critical Discourse Analysis (CDA) whilst grammatical features such as plurality, person and tense were analyzed through the use of Halliday's (1985) Systemic Functional Grammar. The findings from this study revealed that journalists of the articles from The Zimbabwe Herald Online newspaper made use of linguistic and grammatical features that were meant to maintain Zanu- PF ideologies whilst corpus from The Zimbabwean Independent Online newspaper revealed the use of linguistic features that favoured the ideologies of the MDC.
\end{abstract}

Keywords: macrolinguistic complex systems, Zimbabwean political news reports, systemic analysis

\footnotetext{
* Otto Tendayi Mponda: Faculty of Community and Health Sciences, University Western Cape, Birmingham, United Kingdom. Email: otology263@gmail.com.
} 


\section{Introduction}

The article will present the findings that were gathered from analysing a corpus of Zimbabwean online newspapers. Relevant questions and sub-questions from Fairclough's (1989) model for analyzing written texts will be used to explain the ideological standpoints depicted by the vocabulary and grammatical features identified in editorial articles, from The Zimbabwe Herald Online, reporting on politically related events preceding Zimbabwe's, yet to be dated, presidential election. Three political parties namely Zanu-PF, MDC-T and MDC-M constitute Zimbabwe's current ruling inclusive government, which is why it is interesting to examine how the three are represented by The Zimbabwe Herald Online, which happens to be Zimbabwe's only news publisher and printer with a legal tender to operate as a publishing company in Zimbabwe.

Critical discourse analysis (CDA) will be used as an analytic tool. Fairclough's (2001) CDA is an ideal tool for testing the neutrality of the editorial articles published in The Zimbabwe Herald Online as it reveals whether, or not, the vocabulary and grammatical features identified reflect any ideological practices that may be in favor of one political group over others. Vocabulary findings, such as the use of words with meaning relations, will be analyzed from a corpus of 30 articles through the use of concordance software called Antconc 3.2.1 that was developed by Laurence Anthony. Grammatical features such as passive sentences, foregrounding and nominalization will be presented in the form of tables. In order to be able to effectively analyze the grammatical findings in tables, the analysis shall involve the use of Halliday's (1985) systemic functional grammar (SFG) where relevant. SFG facilitates a grammatical analysis of the experiential, textual and cohesive values of the language used in the texts analyzed. A multidimensional use of CDA in collaboration with SFG, in particular when studying grammatical features, was necessary as no single theory could have managed to provide an absolute framework for critically analyzing grammatical features from an ideologically functional perspective. Relevant questions and sub-questions from Fairclough's (1989) model for analyzing texts will be used as titles and sub-tiles when presenting the findings. The findings that emerged from this study provide answers to the following five research questions:

a) What is the communicative purpose behind the use of lexical and grammatical features by writers of editorial articles published in The Zimbabwe Herald Online?

b) How does language reflect power relations between the three political parties, Zanu-PF, MDC-T and MDC-M that are currently involved in Zimbabwe's inclusive government?

c) How and why are linguistic features used by politicians whose direct quotations are cited in the editorial articles analyzed?

d) Why are the quotations chosen for publication by the editors when reporting? 
e) What ideologies and biases are encoded in the language used in the editorial articles from The Zimbabwe Herald Online?

\section{Vocabulary features}

\subsection{What experiential values do words have?}

The ideational use of language in a clause is realized through the experiential metafunction. According to Eggins (2004) the experiential metafunction deals with how reality is represented through language use. Through the use relevant questions from Fairclough's (1989) model for analyzing texts, this section will look at how words are used to represent reality and fulfill the ideological standpoints of the editorial articles published by The Zimbabwe Herald Online between the $1^{\text {st }}$ of May and $30^{\text {th }}$ of June 2011. This section will begin by examining how words are ideologically contested to have ideational meaning in the articles analyzed.

\subsection{Are words ideologically contested?}

Words were ideologically contested in the editorial articles analyzed. An ideology is a closely organized system of beliefs and values that shape the way a group, such as The Zimbabwe Herald Online, understands and represents the world through its reporting. The use of Fairclough's CDA will help in understanding why political news is reported in certain distinct ways by The Zimbabwe Herald Online. Bennwell and Stroke (2006:44) mention that CDA is an "interdisciplinary branch of linguistics that attempts to explore the ideological workings of language in representing the world". An example below shows how words are ideologically contested, by the journalist, to prove how much of a confused party the MDC-T is in reality. The article reads:

'From the "Mugabe must go!" mantra that was the party's clarion call since its launch on September 111999 - our own 9/11 - which made Morgan a bin Laden equivalent, on account of the ruinous sanctions, it is now "Mugabe must stay!",

In the example above, the MDC-T party is portrayed to be retracting from an initial statement that it had made in 1999 about its demand for President Mugabe to exit power. The imperative sentence 'Mugabe must go!' is ideologically contested to 'Mugabe must stay!' with the latter reported to be made recently, in 2011 by MDC-T, in a bid to confuse Zimbabweans and consequently have the next presidential election delayed. From a CDA perspective, the intransitive verbs 'go' and 'stay' contest ideologically as the MDC-T party is thought, by The Zimbabwe Herald Online writer, to be a confused party that does not have a clear stance on Mugabe. Another instance of words being ideologically contested by the writer is in the use of the words' insisting' and 'against' as shown below: 
Macrolinguistic Complex Systems in Zimbabwean Political News Reports: A Systemic Analysis

'It just strikes me as odd that President Mugabe - whom the MDC-T casts as a treacherous dictator - is the one insisting on elections while Tsvangirai, the MDC-T and the coterie of Western-sponsored NGOs are all against elections.'

As stated above, the verb 'insisting' and the preposition 'against' are ideologically contested by the writer to present conflicting views, between Zanu-PF and the MDC-T party, on holding the election in 2011 , once the inclusive government is dissolved. The preposition 'against' indicates MDC-T's opposition to the idea of the presidential election being held in 2011, a move which Zanu-PF claims to be against the Global Political Agreement (GPA) constitution. Thus, the reader is made to presuppose that the MDC-T party is a deviant political party that does not abide to the GPA constitution. On the other hand President Mugabe, the leader of Zanu-PF, is portrayed as a strict follower of the GPA constitution and the only person who has been insisting on the election to take place without any delays. The use of ideologically contested words which represent both political parties in either a negative or positive way confirms The Zimbabwe Herald Online's ideology of always presenting Zanu-PF in a better light at the expense of the MDC-T party.

The use of ideologically contested words is also evident in a quotation, from Zanu-PF national chairman Cde Simon Khaya Moyo, below:

'You can't mix water and oil. Our ministers from Zanu-PF are not allowed to travel to Europe and the MDC ministers are allowed to travel around the world and you expect such a Government to work.'

The ideological use of the words 'oil' and 'water' reveals power struggles between Zanu-PF and the MDC-T party. Although oil and water are both liquids the truth of the matter is that they can never blend together well. In the above example, the nouns 'water' and 'oil' are ideologically contested in order to stress on how much Zanu-PF and MDC-T can never work in unison as an inclusive government since the two political parties are incompatible with each other. Thus, the oil-water contrast signifies the tensions that exist within the inclusive government itself. According to Cde Simon Khaya Moyo the unsuccessful union of Zanu-PF and MDC-T can only be blamed MDC-T members who are seen by Zanu-PF as a puppets of western states given the fact that they (MDC-T) are the only ones allowed to travel to Europe whilst their Zanu-PF counterparts are not allowed to travel to Europe due to traveling sanctions leveled against them. A critical discourse analysis reveals that one of Zanu-PF's ideologies is to present the MDC-T party as a puppet political party which can never be able to defend the sovereignty of the country against western influence. Zanu-PF on the other hand is portrayed as undergoing sanctions as a result of being an independent party that does not bow down to western dictatorship. The inclusion of Cde Khaya Moyo's contrast of the positive and negative forms of the intransitive verb 'allowed/ not allowed' (to travel abroad), in the article, is a way of seeking 
sympathy from the readers in a quest to persuade them in believing that Zanu-PF officials are unfairly treated by the western community because of the MDC-T party which is thought to have probed western states to sanction Zanu-PF officials from traveling abroad.

In an article extracted below the words Zanu-PF and MDC-T are ideologically contested by Zanu-PF national spokesperson Cde Rugare Gumbo in order to present the strengths of Zanu-PF whilst highlighting the weaknesses of the MDC-T party. A part of the report reads:

"'They say they are a party of excellence and if they are really a party of excellence why are they afraid of the masses?" he asked.

He said Zanu-PF had a clear agenda of economic empowerment and defending the country's sovereignty but the MDC-T did not have any home grown solution to challenges besetting the country's economy.

"Zanu-PF talks of land reform and empowerment and the MDC-T does not have anything. They can't even give civil servants anything. President Mugabe said civil servants salaries will be increased next month but the MDC-T is against the increase, " he said.'

The parties Zanu-PF and MDC-T are ideologically contested above in order to present Zanu-PF in a very positive light at the expense of the MDC-T party. It is interesting to note that the MDC-T party is the only opposition party which is negatively referenced to whilst the other opposition party MDC-M is not mentioned at all. Zanu-PF is said to have an agenda of economic empowerment and defending the country's sovereignty whilst the MDC-T party is reported to have no immediate solutions to the problems facing the country. Such negative remarks about the MDC-T party, ahead of Zimbabwe's forthcoming presidential election, is meant to portray the opposition party as a wanting party that has no manifesto. The MDC-T party is placed in a bad spot light in order to satisfy one of the ideologies of Zanu-PF that MDC-T will never fully govern Zimbabwe as it is thought to be against the interests of the Zimbabwean people. President Mugabe is reported to have talked about increasing the wages of the civil servants, a move which the MDC-T party is reported to have totally disputed. The claim that the MDC-T party is against the civil servants' salary increase portrays them as working against the interests of the civil servants. Thus, the MDC-T party is seen as not deserving of the public vote as they have nothing to offer to civil servants and the people of Zimbabwe at large.

\subsection{What ideologically significant meaning relations are there between words?}

The corpus created from articles published in The Zimbabwe Herald Online shows that the words 'suspected MDC-T' are linked to aggressive hyponym meaning relations such as assaulted and attacked, among others. Hyponyms are defined by Fairclough (2001) as when the meaning of one word is, so to speak, included within the meaning of another word. 
Figure 1 below shows how the MDC-T party is associated with unruly behavior by writers of articles published in The Zimbabwe Herald Online.

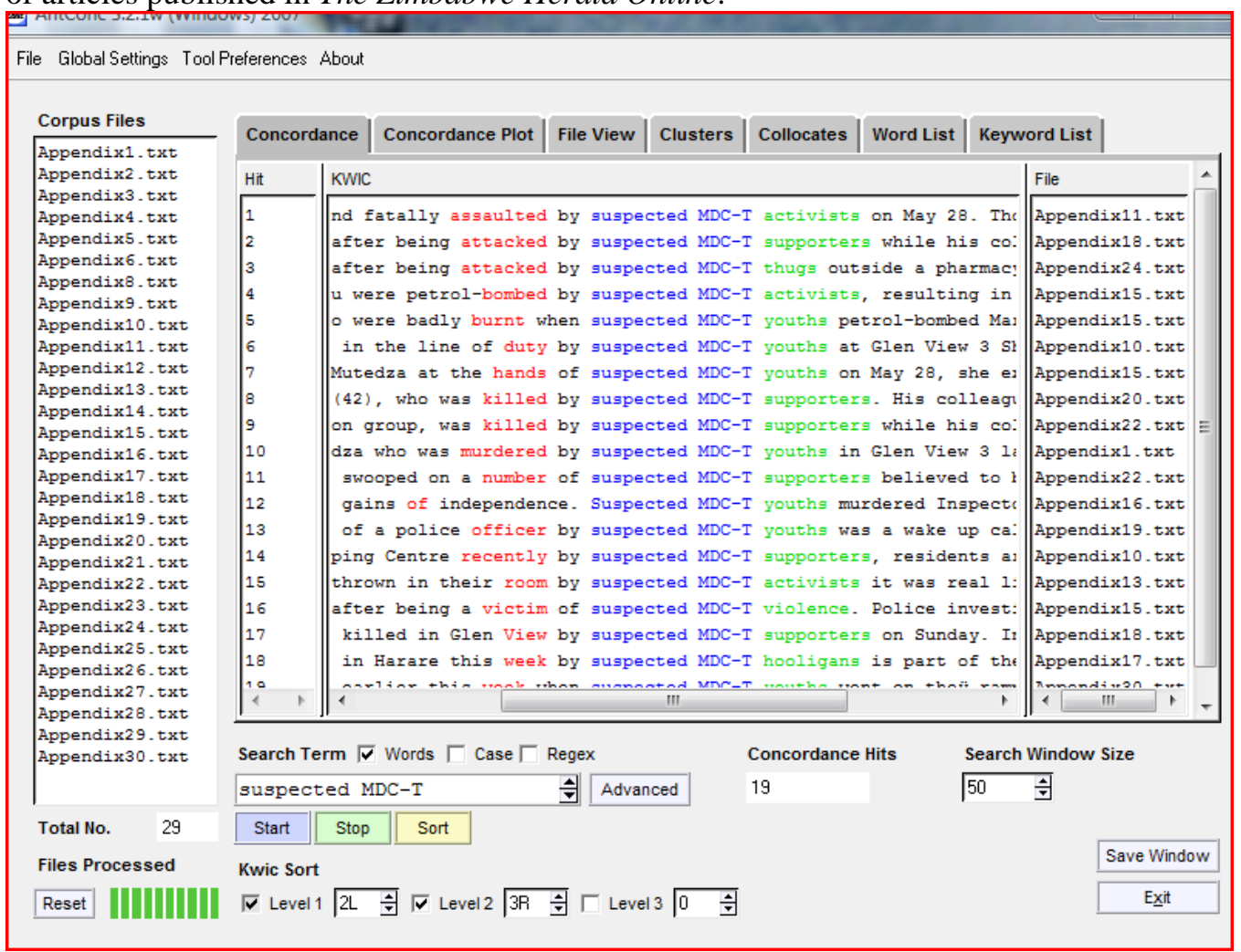

Figure 1. Showing the Hyponyms Assaulted, Attack, Bombed, Petrol-Bombed, and Killed on the Left Side of the Words 'suspected MDC-T'

As reflected in figure 1 above, the word 'suspected' is used to implicate the MDC-T party of scandalous acts. Verbs preceding the words 'suspected MDC-T' such as 'attacked, assaulted, petrol-bombed, badly burnt, killed and murdered' are all hyponyms which specify the nature of violence that is thought to have been instigated by members of the MDC-T party. The destructive hyponyms belong to one ideological discourse type, which is terrorism. Ideally, the word 'suspect' should only be used when the real perpetrator of the crime is not known. However, the writers of The Zimbabwe Herald Online quickly report the MDC-T party as suspects thereby assuming without concrete evidence that the MDC-T youths and supporters are definitely the ones who committed the different offences highlighted in red, to the left of the words 'suspected MDC-T' in figure 1 above. A CDA analysis shows that writers of the articles published in The Herald Online never use 
anti-Zanu-PF accusations such as 'suspected Zanu-PF supporters' but instead always blame it all on 'suspected MDC-T supporters' thereby revealing prejudiced reporting.

Information in figure 1 occurring at the right side of the words 'suspected MDC-T' reveals the various names which MDC-T members are referred to as by the writers, which are MDC-T activists, MDC-T supporters, MDC-T thugs, MDC-T youths, MDC-T supporters and MDC-T hooligans. The use of the near synonyms 'thugs' and 'hooligans' reveals a negative biased attitude against MDC-T members by the writers of the articles from The Zimbabwean Herald Online news. The evidence in figure 1 reveals the words use of hyponyms and synonyms as being used to negatively portray a bad image of the MDC-T party in the minds of the reader by the writers.

Another instance showing the ideological use of words with significant meaning relations is shown in figure 2 below:

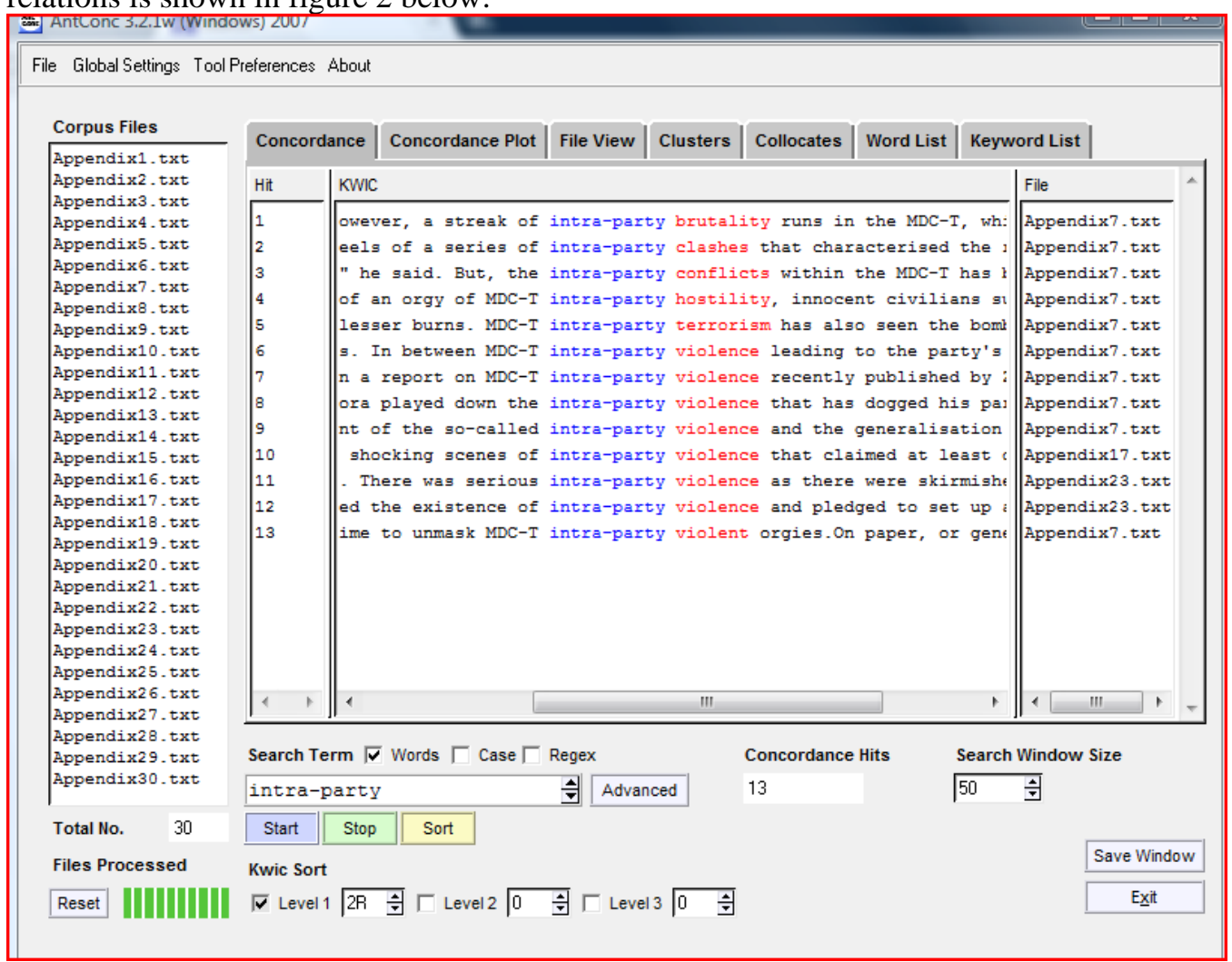

Figure 2. Showing Meaning Relations between Near Synonyms Such as Clashes, Conflicts, Hostility and Violence Appearing to the Right of the Word 'intraparty'

The near synonyms appearing on the right side of the word 'intraparty' above reveal the different realizations of the tension that is reported to be within the MDC-T party. Near 
synonyms are words that can be mutually substitutable with little effect on meaning (Fairclough, 2001). The intra-party tension within the MDC-T party is realized by writers of The Zimbabwe Herald Online articles as 'intra-party brutality, intra-party clashes, intra-party conflicts, intra-party terrorism and intra-party violence'. These near synonyms identified reveal that the MDC-T party is portrayed as a troubled party that is on the verge of breaking point ahead of the anticipated historical Zimbabwean presidential election. The semantic findings from this current study are inline with those from Ndlovhu's (2006) study, in which editors of articles published in The Zimbabwean Herald print newspaper reporting on Zanu-PF's land reform programme which had begun in the year 2000, made use of discourse control and semantic twists meant to support Zanu-PF's land reform policies. Likewise, the near synonyms identified in this current study are used by writers of The Zimbabwe Herald Online as propaganda to ideologically present the MDC-T as a dysfunctional political party that is not capable of handling bigger affairs of the country given the fact that they can not even handle their own intra-party affairs.

\subsection{What expressive and propositional meanings do words have?}

This section seeks to examine the expressive and propositional meanings behind the use of words. According to Baker (1992) the expressive function can be used to show the attitude of the speaker or writer. Propositional meanings, on the other hand, refer to statements that are believed to be true in circumstances that involve the speaker/writer and the hearer/reader (Potts, 2003). The adjective 'dear', used by The Zimbabwe Herald Online journalist, has expressive meaning as shown below:

'HAVE you, dear reader, taken time to decode the messages from the personalised party,

MDC-Tsvangirai over the GPA and this whole election business?'

The writer of the article above uses the adjective 'dear' to affectionately address the reader. The use of this term of endearment by the writer is done in order to personalize his/ her relationship with the reader making it easy for him/ her to persuade them to consider his arguments against the MDC-T party. The writer further shows his/ her biased support for Zanu-PF by writing:

'Don't get me wrong dear reader. I am not saying if elections are held, President Mugabe will go, no.'

As reflected above, the writer still addresses the reader as 'dear' and goes on to clarify that his/ her argument that the presidential election should be held soon did not mean that Zanu-PF would loose in any way. A critical discourse analysis reveals a biased ideology towards Zanu-PF whereby the writer tries to get the reader to support his/ her anti-MDC-T views by getting affectionate with them and making them evaluate the situation from his/her point of view. Such emotive use of language by the writer in defense of Zanu-PF 
reveals shared common interests between Zanu-PF and the writers of articles published in The Zimbabwe Herald Online.

A word can have both expressive and propositional qualities as shown by the use of 'whining' in a quotation from Zanu-PF national chairman Cde Simon Khaya Moyo below:

'He said the MDC-T had no agenda except to say (President) Mugabe must go. "They are always

whining. They have no agenda except that Mugabe must go. Everyday its remove Mugabe," he said.'

As shown in the above example, the MDC-T party is portrayed as always 'whining' about Mugabe's exit from power. The word 'whining' has a connotative meaning which serves the expressive function of showing disgust at how the MDC-T keeps on complaining endlessly about why Mugabe is not resigning from his post as Zimbabwe's president. The use of the modal verb 'must' indicates that the MDC-T strongly feels that Mugabe is compelled to exit from power as they think he was unconstitutionally installed as president since he automatically won the 2008 re-run presidential election in which he was the only participant as all his rivals had withdrawn their candidatures.

The direct quotations from MDC-T officials chosen for publication in The Zimbabwe Herald Online articles always reveal negative information about the MDC-T party as opposed to those quoted from Zanu-PF officials. In another article, a Senior MDC-T official and co-Home Affairs Minister Mrs Makone is quoted to have revealed how much she supported political violence together with her party's youths:

'Mrs Makone exonerated Mr Tsvangirai for inciting violence, saying it was her and other members of the party's youth assembly who wanted revenge.

"My Prime Minister never said such words. It was myself and the youth that spoke about violence," she said.

However, Zanu-PF yesterday condemned the cruelty behind MDC-T leadership's call for violence and urged its supporters to be peaceful in the face of open hostility from a partner in the inclusive Government.'

In the above example, the expressive word 'revenge' is used by the MDC-T senior official to justify the reason why the MDC-T supported political violence. On the contrary, the word 'cruelty' is used by the writer to reveal his/ her disgust in MDC-T's love for violence. The word 'cruelty' is inherently expressive and shows disapproval in the hostile attitude reflected by members of the MDC-T faction. Cruelty as an expressive word is a very strong word to be used and shows the extent to which the MDC-T violence is despised by both the writer of the article and Zanu-PF itself. As reflected in the example above, the senior MDC-T member and MDC-T youths are represented as supporting violence whist Zanu-PF as a whole is represented as disapproving of MDC-T's violent behavior.

The writers of articles published in The Zimbabwe Herald Online also use the expressive compound word 'MDC-T violence' as shown in figure 3 below. 
Macrolinguistic Complex Systems in Zimbabwean Political News Reports: A Systemic Analysis

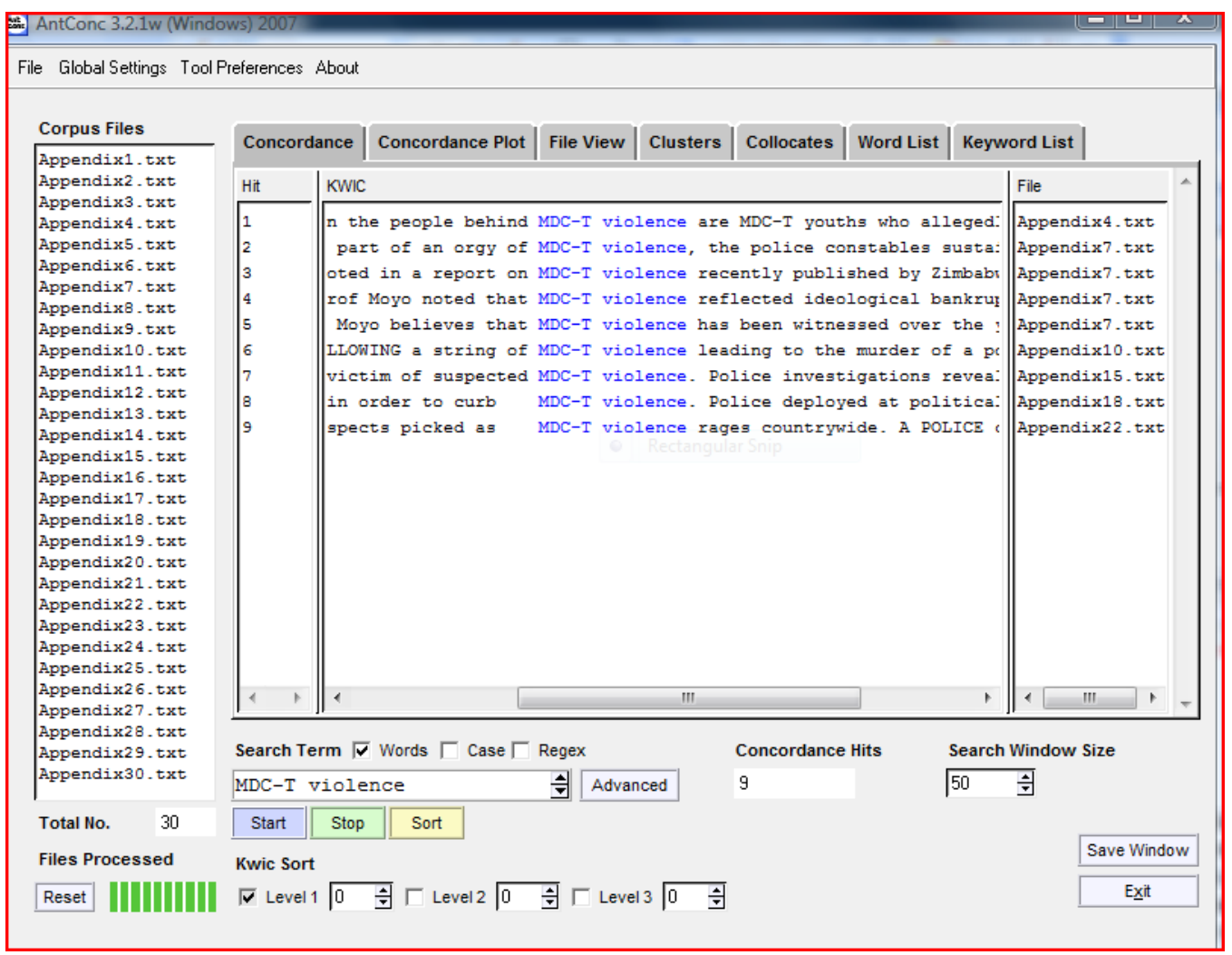

Figure 3. Showing the Use of The Expressive Compound Word 'MDC-T violence'

As shown in figure 3 above, the MDC-T is represented as a party that is manifested with violence. The word 'MDC-T' collocates with the word 'violence' thereby revealing an ideological standpoint on the part of The Zimbabwean Herald online. As reflected in the first sentence in figure 3 above, the people who are always reported to be agents of political violence are MDC-T members. The ideology of a violent MDC-T party is a dominant theme in most articles published by The Herald Online. Apart from the use of expressive meaning The Zimbabwe Herald Online writers also use words with propositional meaning. Propositional meanings provide the basis for verification on whether or not a statement is true or false. They can be used whenever it is believed that there is shared meaning between the involved participants as shown in a quotation from Zanu-PF national spokesperson Cde Rugare Gumbo below:

'He said if MDC-T resolved to pull out of the process completely, it simply must notify the facilitator so that we continue with the other MDC formation and civic organisations.'

The word 'simply' is a completely expressive word whilst 'must' has the qualities of being both expressive and prepositional. The use of the word 'must' shows how much the 
speaker, cited in the article, feels strongly about a given opinion. The statement above is meant to make a convincing argument against MDC-T's intended withdrawal from the inclusive government as it is viewed by Zanu-PF as simple shared knowledge that any change of heart between the three political parties involved should be communicated to the Global Political Agreement facilitator who in this case happens to be the Southern African Development Committee (SADC), which is currently headed by South African president Mr. Jacob Zuma. From a CDA perspective reference to the facilitator reveals a higher source of power which should be consulted whenever any changes occur in the Zimbabwean inclusive government. If the MDC-T party pulls out of the inclusive government without communicating with the facilitator there is a subtle hint, as reflected by the expressive words used, that Zanu-PF will not be impressed with MDC-T's move. It is thought that the MDC-T should know better than just to think of pulling out of the inclusive government without following proper procedures. The MDC-T party is hereby portrayed as a political party which is feared to be, ignorant, lacking knowledge of the inclusive government's rules and regulations. Another example of the expressive and propositional use of language is when Zanu-PF Politburo member Cde Tendai Savanhu makes use of the word 'must definitely' as shown below:

“"Zanu-PF can not loose in the forthcoming elections as it must definitely continue defending the county's sovereignty as a revolutionary party, " he said.'

As shown in the above example, the words 'must definitely' are used to emphasize and draw attention to the ideology that Zanu-PF will rule Zimbabwe forever as it is the revolutionary party which was responsible for Zimbabwe's 1980 independence against the British regime. It is assumed that by virtue of Zanu-PF being the revolutionary party, no other political party has the ability to defend the country's sovereignty as much as Zanu-PF. Since it is shared knowledge between all Zimbabweans that Zanu-PF is the revolutionary party, the Zanu-PF official quoted makes it his prerogative to influence people to vote for Zanu-PF by capitalizing on it being the revolutionary party. Zanu-PF officials use expressive and propositional words in their speeches to proclaim power and dominance over the MDC-T party. A CDA analysis reveals that The Herald Online calculatingly chooses specific direct quotations of speech, from Zanu-PF officials, in order to blend into the same anti-MDC-T ideologies.

\subsection{What metaphors are used?}

There is the use of metaphors in the editorial articles, gathered from The Herald Online, which report on the events surrounding Zimbabwe's forthcoming presidential elections. According to Oxford dictionary meaning a metaphor is defined as a figure of speech in which an implied comparison is made between two unlike things that actually have something in common. The type of metaphor that is going to be embraced in this analysis 
is what Tomlin (2011) refers to as 'the blueprint metaphor' of discourse. When using the blueprint metaphor of discourse, the speaker or writer holds a conceptual representation of events or ideas which he intends should be replicated in the mind of the listener or reader (Tomlin, 2011). An example below of a blueprint metaphor comes from an editorial article from The Zimbabwean Herald Online newspaper whereby The Herald writer links the MDC-T to acts of terrorism.

From the "Mugabe must go!" mantra that was the party's clarion call since its launch on September 111999 - our own 9/11 - which made Morgan a bin Laden equivalent, on account of the ruinous sanctions, it is now "No Mugabe must stay!",

The use of the terrorist metaphor ' $9 / 11$ ' that equates the MDC-T leader, Morgan Tsvangirai, to the late terrorist Osama Bin Laden is an indication that the MDC-T leader is portrayed as a threat to Zimbabwe's sovereignty as he is thought to have advised western countries like the United States and the United Kingdom to impose illegal sanctions on Zimbabwe until President Mugabe stepped down from power. Consequently, Tsvangirai is placed in the same league as that of the United State's most sought terrorist, Osama Bin Laden in order to show the extent to which Tsvangirai is deemed as bad news to Zimbabwe by the editors of The Herald Online. Osama Bin Laden was once the leader of the Al-Qaeda, which is a terrorist movement that was responsible for carrying out a series of suicide attacks in United States of America on the 11th of September in 2001, otherwise known as the September 11 attacks. The fact that Tsvangirai's political party was launched on the 11th of September in 1999 is referred to by the editor as Zimbabwe's own September 11 attacks thereby labeling the launch of the MDC-T party as the worst political milestone ever to occur in Zimbabwe. A critical discourse analysis reveals that The Zimbabwe Herald Online has a biased pro-Zanu-PF ideology which is set to discredit the MDC-T party at all costs by associating the political party with dubious and terrorist related activities. Findings from this current study confirm with Ndlovhu's (2006) study whose findings established the use of discourse control and semantic twists, in The Zimbabwean Herald print newspaper, that were always in support of ZANU-PF's fast-track land reform programme which had begun in the year 2000.

The MDC-T party is portrayed as a bogus political party whose main intention is to delay the forthcoming presidential elections at all costs as evidenced in the writer's report speech referencing Zanu-PF national spokesperson Cde Rugare Gumbo below:

'He said MDC-T was playing political games to delay elections'

The writer's use of Cde Rugare Gumbo's description of MDC-T's involvement in politics as 'playing political games' is meant to portray the opposition party in a negative way. The MDC-T party is portrayed as a political party that has no serious political motives apart from finding amusement in delaying the forthcoming presidential election. The use 
the metaphor makes the reader presuppose that the other two rival political parties Zanu-PF and MDC-M are the only two serious parties who, unlike MDC-T, have genuine political interests in the presidential elections and as such do not have time to engage themselves in playing political games. A critical discourse analysis reveals that the MDC-T is represented in a bad way by the paper in order to satisfy the ideology held by The Zimbabwe Herald Online, of MDC-T not being a party worth voting for as it is only after playing political games and nothing more.

Zanu-PF members quoted in The Herald portray MDC-T as a confused party as evidenced in Cde Gumbo of Zanu-PF's use of the word 'U-turn' a term usually used for directions when driving.

'Cde Gumbo said the three Copac co-chairpersons had agreed on everything regarding the handling of data collated from the people during outreach programme and it was baffling why MDC-T was making a U-turn.'

As evidenced in the words from Zanu-PF spokesperson Cde Gumbo, quoted in the editorial article, the MDC-T is reported to have unceremoniously changed its mind on previously made agreements between Zanu-PF, MDC-M and MDC-T. From a CDA perspective, the use of the driving metaphor 'U-turn' represents an ideology by The Herald newspaper whereby MDC-T is portrayed as unreliable as it suffers from indecision whilst Zanu-PF and MDC-M are represented as more organized and credible political parties. Zanu-PF and MDC-M are hardly represented in a bad light as most negative metaphors used in the articles seem to target MDC-T. Another metaphor that was used by Zanu-PF's Cde Gumbo in the same article is 'ideologically bankrupt':

'They (MDC-T) have no agenda. They are ideologically bankrupt and they have nothing to offer to the people.'

Considering the use of the finance metaphor 'bankrupt' by a Zanu-PF member to describe MDC-T's ideologies, it is evident that the direct quotations chosen for publication in editorial articles from The Zimbabwean Herald Online are meant to reinforce the newspaper's bias towards Zanu-PF and discredit the MDC-T party. A CDA analysis reveals that portraying the MDC-T party as a political party that is ideologically bankrupt paints a bad image of the party especially to the readers. Publishing material which portrays a negative image of the MDC-T is not in line with the expectations required of a democratic news publisher in a country where there is currently an inclusive government. Thus, despite The Zimbabwe Herald Online claiming to be fair in its reporting, it has bias towards Zanu-PF as the content in its articles down size MDC-T through the use of linguistic features such as negative blue-print metaphors that are meant to instill elements of doubt in the minds of its MDC-T supporting readership. 
Editors of The Herald Online also make use of the geographic metaphor 'landslide' to explain the nature of victory that is in store for Zanu-PF in the forthcoming presidential to describe Zanu-PF's anticipated triumph in the forthcoming presidential elections. The writer writes:

'ZANU-PF Mashonaland Central Province has thrown its weight behind the holding of elections this year, arguing the party was ready for a landslide victory.'

The use of the metaphor 'landslide victory' purports Zanu-PF as the automatic conqueror in the forthcoming presidential elections. A landslide victory on the part of Zanu-PF presupposes how much little competition both MDC-T and MDC-M bring to the presidential elections. Referencing Zanu-PF's win as a landslide victory shows how much bias the paper has towards that political party as the editors choose statements and quotations which pre-empty the elections by prematurely declaring it as the automatic victor. Thus, a critical discourse analysis of the article reveals that ideology and power are pervasively present in language (Fairclough, 2001).

As shown in the metaphors previously analyzed so far, the main agenda behind the editorial articles published in The Herald online newspaper is to intimidate MDC-T supporters by always presenting Zanu-PF as more powerful. In the following example, The writer of the article extracted below mentions that any talk of the next presidential elections immediately makes the MDC-T party tremble with fear such that it develops 'goose pimples'.

'This is why any talk of elections this year brings MDC-T out in goose pimples.'

The Herald Online's ideological position of belittling the MDC-T in favor of its strongest presidential election rival, Zanu-PF, is shown in the sentence above. The idea, suggested by the writer, of the MDC-T party growing goose pimples as a sign of fearing Zanu-PF defeat in the forthcoming presidential elections clearly betrays the newspapers presumptions that Zanu-PF is the definite victor of the next presidential election. In retrospect, a critical discourse analysis of some of the blue print metaphors used in articles from The Herald Online reveals that its editors have an ideology of presenting Zanu-PF as the most powerful political party that will only rule Zimbabwe regardless of any election. Despite The Herald Online's claim that it is in unbiased support of the current inclusive government, which was formed in 2008, the blue print metaphors used in its editorial articles betray one of its dominant ideologies of Zanu-PF being the only party that is deemed to rule Zimbabwe forever owing to it being a revolutionary party that led the people of Zimbabwe to their freedom from British colonial bondage in 1980.

\section{Grammatical features}

2.1 What experiential values do grammatical features have? 
This section will examine the types of grammatical processes that predominate in editorial articles published in The Zimbabwe Herald Online. Other features that will be looked at, in order to find out if they reveal any ideological standpoints on the part of the writers, include nominalization as well as the use of passive sentences, amongst others. The use of passive sentences shall be examined first.

\subsubsection{Are sentences active or passive?}

The five basic elements that constitute the clause structure are subject, predicator, object, complement and adjunct. According to Halliday and Mathiessen (2004), syntactic principles established by medieval grammarians reveal that each clause contains one element that can be identified as its 'subject'. Thompson (1996) mentions that when studying functional grammar a subject is defined as a normative element that acts as the main concern of the message. This section will make use of systemic functional grammar to find out the reasons why sentences are made active or passive by editors of articles published in The Zimbabwe Herald Online.

The predicator is identified by a verbal group and is usually called 'the action word' of a clause. The verbal group is the constituent that functions as finite plus predicator (or as predicator alone) in the mood structure (Halliday and Mathiessen, 2004). The relationship between the subject and predicator is one such that, alone, they can both constitute a meaningful clause. Kroeger (2005) mentions that 'subject' is different from 'agent' in that the former is based on word order and importance to the sentence whilst the latter is explicitly based on its relationship to the action stated in the verb. The grammatical functions of the 'doer' (agent) and the 'done to' (recipient of the action stated in the predicator) will be used to examine how the three political parties (Zanu-PF, MDC-T and MDC-M) involved in Zimbabwe's current inclusive government are referred to as either actors or recipients of any actions. The compliment, which is defined by (Halliday and Mathiessen, 2004) as a referent to either the agent or recipient in a clause, will also be considered in the analysis where necessary. Another grammatical aspect that will be noted is the adjunct, which Halliday and Mathiessen (2004) define as information that supports the action performed in the clause. In another example the journalist places 'a Zanu-PF member' in subject position as the main concern of the message:

'A ZANU-PF member was last week fatally assaulted by more than 10 suspected MDC-T members in Mbare as political violence continued unabated in the suburb.'

Table 1. Showing Passive Sentence with a Zanu-PF Member as the Victim of MDC-T Violence

\begin{tabular}{|l|l|l|l|l|l||}
\hline $\begin{array}{l}\text { A Zanu-PF } \\
\text { member }\end{array}$ & was & last week & fatally & by more than 10 & in Mbare as political violence \\
assaulted & $\begin{array}{l}\text { suspected MDC-T } \\
\text { members }\end{array}$ & $\begin{array}{l}\text { continued unabated in the } \\
\text { surburb. }\end{array}$ \\
\hline
\end{tabular}


Macrolinguistic Complex Systems in Zimbabwean Political News Reports: A Systemic Analysis

\begin{tabular}{|c|c|c|c|c|c|}
\hline Goal & \multicolumn{3}{|c|}{ Process } & \multirow{2}{*}{\begin{tabular}{|l} 
Agent \\
Adjunct
\end{tabular}} & \multirow{2}{*}{$\begin{array}{l}\text { Location } \\
\text { Adjunct }\end{array}$} \\
\hline Subject & Finite & Adjunct & Predicator & & \\
\hline Mood & & \multicolumn{4}{|l|}{ Residue } \\
\hline Nominal group & Verbal & roup & & Prep. phrase & Prep. phrase \\
\hline
\end{tabular}

In the sentence in table 1 above, agency is clear as the article declares more than ten MDC-T members as the prime suspects of the fatal assault. The 'Process' reveals that the sentence is in passive form. The sentence is in passive form in order to place the Zanu-PF recipient of the action in subject position, for emphasis. Halliday and Matthiessen (2004) mention that process is the beginning point of clause representation. The process involved in the clause in table 1 is material whereby two participants are involved with MDC-T being the actor who performs the fatal attack whilst 'a Zanu-PF member' is the goal to which the action is extended. The nominal group 'A Zanu-PF member' appears before the finite 'was' as the subject, which makes the sentence a declarative clause (Thompson, 2004). The mood is defined by (Halliday and Mathiessen, 2004) as the element that carries the burden of the clause as an interactive event. Thus, the finite 'was' which reveals primary (past) tense and the adjunct 'last week' are an interesting point of reference in both the mood and residue as they render the assault allegations arguable given the fact that police investigations were still underway. Nevertheless, despite police investigations still being undertaken, the MDC-T party is already being assumed as the obvious suspect. Labeling the MDC-T party as immediate suspects betrays The Zimbabwe Herald Online's ideology of representing the MDC-T party as violent. Another example of agency, in the form of violence, being clear comes from a sentence in an editorial article. The writer reports:

'Cde Jimu Kunaka - was assaulted by MDCT youths at a food court in the city.'

Table 2. Showing Passive Sentence with a Zanu-PF Comrade as the Victim of MDC-T Violence

\begin{tabular}{||l|l|l|l|l||}
\hline Cde Jimu Kunaka & was & assaulted & by MDCT youths & at a food court in the city. \\
\hline Goal & Process & Agent & Location \\
\hline Subject & Finite & Predicator & Adjunct & Adjunct \\
\hline Mood & \multicolumn{2}{|l|}{ Residue } \\
\hline Nominal group & \multicolumn{5}{|l|}{ Verbal group } & Prepositional Phrase & Prepositional phrase \\
\hline
\end{tabular}

Information in table 2 above reveals how the agent 'MDC-T youths' are reported to have assaulted a comrade at a food court in the city of Harare. The goal 'Cde Jimu Kunaka' is placed in subject position in the declarative clause in order to give prominence to his social affiliation and him being a victim of violence. In Zimbabwe people who are referred to as comrades (Cde) are those who fought in its liberation struggle in the 1980s. Thus, 


\section{Otto Tendayi Mponda}

comrades are highly respected people on the Zimbabwean political scene. Through the use of the predicator 'assaulted' MDC-T supporters are reported to have been violent towards one of the people who contributed towards Zimbabwe's freedom from British colonialism. Since nearly all the senior officials in Zanu-PF are comrades the assault of a comrade qualifies the MDC-T party as disrespectful of those people who are highly regarded by Zanu-PF and the society at large.

The MDC-T party is reported to attack anybody from Zanu-PF comrades to its own senior party officials. The Zimbabwe Herald Online reporter writes that MDC-T party youths attacked a senior member of their own party:

'MDC-T Matabeleland North provincial chairperson Mr. Sengezo Tshabangu was reportedly beaten up by party youths at Harvest House yesterday ahead of today's national council meeting.'

Table 3. Showing Passive Sentence with an MDC-T Senior Party Leader as a Victim of MDC-T Violence

\begin{tabular}{|l|l|l|l|l||}
\hline $\begin{array}{l}\text { MDC-T Matabeleland North } \\
\text { provincial chairperson Mr. } \\
\text { Sengezo Tshabangu }\end{array}$ & was & $\begin{array}{l}\text { reportedly } \\
\text { beaten up }\end{array}$ & $\begin{array}{l}\text { by party } \\
\text { youths }\end{array}$ & $\begin{array}{l}\text { at Harvest House yesterday } \\
\text { ahead of today's national } \\
\text { council meeting. }\end{array}$ \\
\hline Goal & Process & Agent & Location \\
\hline Subject & Finite & Predicator & Adjunct & Adjunct \\
\hline Mood & Residue \\
\hline Nominal group & \multicolumn{2}{|l}{ Verbal group } & $\begin{array}{l}\text { Prepositional } \\
\text { phrase }\end{array}$ & Prepositional phrase \\
\hline
\end{tabular}

As shown above, the title 'MDC-T provincial chairperson' is made part of the subject in order to place focus on the status of the person involved. Despite Mr. Sengezo Tshabangu being a high ranking official he still got beaten up by MDC-T youths regardless. From a CDA perspective the idea of MDC-T party supporters beating up one of their own senior party leaders, who happens to be the goal of the action, portrays them as agents of violence and reveals how the party is represented as rowdy, confused and undisciplined. The location 'at Harvest House...' reveals that the beating took place at the main headquarters of the MDC-T party, a place thought by Zanu-PF to be where the MDC-T masterminds its violent attacks.

In an editorial article from The Zimbabwe Herald Online, MDC-T supporters are reported to have been victims of violence but the agent is not stated. The writer reports:

'MDC-T supporters were bleeding according to reliable eyewitnesses at a meeting aborted due to violence at their party offices in Bulawayo on Friday.' 
Macrolinguistic Complex Systems in Zimbabwean Political News Reports: A Systemic Analysis

Table 4. Showing Passive Sentence in which MDC-T Supporters Are Victims of Violence

\begin{tabular}{|l|l|l|l|l||}
\hline MDC-T supporters & were & bleeding & $\begin{array}{l}\text { according to reliable } \\
\text { eyewitnesses }\end{array}$ & $\begin{array}{l}\text { at meeting aborted due to } \\
\text { violence at their party offices in } \\
\text { Bulawayo on Friday }\end{array}$ \\
\hline Medium & Process & Source & \\
\hline Subject & Finite & Predicator & Adjunct & Adjunct \\
\hline Mood & Residue & Prepositional phrase & Prepositional phrase \\
\hline Nominal group & Verbal group &
\end{tabular}

As reflected in table 4 above, agency is not clear which is why there is the structure Medium + Process. It is not clear whether MDC-T supporters fought each other or whether some Zanu-PF supporters or policemen had attacked them during an MDC-T meeting in Bulawayo. In a picture accompanying the editorial article, there is a Zanu-PF led policeman holding a button stick on MDC-T supporters. Despite the image of the policeman dispersing the MDC-T supporters from their scheduled meeting, the reason why the MDC-T supporters were bleeding is not given. The idea of not presenting the actor of the violence is to avoid implicating the police or Zanu-PF supporters as possible suspects since The Zimbabwe Herald Online maintains an ideology that the MDC-T party is the only instigator of violence in Zimbabwe. The sentence in table 7 is made passive in order to present the subject 'MDC-T supporters' as the focus of the sentence. The mood of the sentence is declarative in nature as the finite verb 'were' is preceded by the subject. Thus, The Zimbabwe Herald Online makes a fierce campaign to sabotage the MDC-T party by only publishing stories in which its party members as being violent towards Zanu-PF and their own member and never Zanu-PF being the perpetrator of any violence.

2.1.2 What types of process and participants predominate?

The Zimbabwe Herald Online editors make use of foregrounding. The process of foregrounding is predominant in almost all the articles proving that it serves an ideological purpose of representing certain individuals or participants in ways that the newspaper deems necessary. Foregrounding is defined by Hakemulder (2004) as a form of deviation that writers use to deliberately introduce certain information before others so as to achieve a particular effect on the reader.

The theme and rheme are going to be considered when analyzing the processes of foregrounding and nominalization. The theme marks the starting point of a message and occurs at the beginning of the clause whilst the rheme follows after the theme has been identified, constituting the remainder of the clause. An example of foregrounding is seen in the theme in table 5 below: 


\section{Otto Tendayi Mponda}

Table 5. Shows Foregrounding when Reporting on MDC-T Participants Inciting Violence

\begin{tabular}{|l|l||}
\hline \multicolumn{1}{|c|}{ Theme } & \multicolumn{1}{|c|}{ Rheme } \\
\hline $\begin{array}{l}\text { 1.MDC-T leader Mr. Morgan } \\
\text { Tsvangirai... }\end{array}$ & $\begin{array}{l}\text {..has come under fire for making reckless public utterances } \\
\text { that incite violence and create animosity at a time when } \\
\text { Government has initiated a national healing and } \\
\text { reconciliation process. }\end{array}$ \\
\hline $\begin{array}{l}\text { 2.MDC-T president Mr. Morgan } \\
\text { Tsvangirai. }\end{array}$ & $\begin{array}{l}\text {.has confirmed his party's propensity for violence by } \\
\text { urging his supporters to mobilise and use violence in future } \\
\text { elections. }\end{array}$ \\
\hline $\begin{array}{l}\text { 3. Senior MDC-T official and co-Home } \\
\text { Affairs Minister Theresa Makone ... }\end{array}$ & $\begin{array}{l}\text { kindicated Mr. Tsvangirai's call for violence, saying it } \\
\text { was time they extinguished fire with fire. }\end{array}$ \\
\hline
\end{tabular}

As shown in table 5 above, the titles MDC-T leader Mr. Morgan Tsvangirai, MDC-T president Mr. Morgan Tsvangirai and Senior MDC-T official and co-Home.

Affairs Minister Theresa Makone, are foregrounded by the writer for emphasis sake as well as to channel the reader's understanding of the key participants involved in inciting MDC-T violence. According to Halliday and Matthiessen (2004) the theme sets up a local environment, providing a point of departure by reference to which the reader interprets the message. MDC-T party abbreviations are explicitly labeled before introducing the names of the party's president, Mr. Tsvangirai, and its co-Home Affairs Minister, Mrs Makone, in order to mark a point of departure for the reader. As reflected in the information foregrounded in examples 1 and 2 in table 5 above, Tsvangirai is reported to be a leader and an authoritative figure who despite his status goes on to incite violence in people who support his party. However, a conflicting message is given in example 3 above as Mrs Makone vindicates Mr. Tsvangirai for not inciting violence yet he is clearly reported in examples 1 and 2 above as having incited violence. The contrast in Tsvangirai's stance on MDC-T violence is meant to portray the MDC-T party as inconsistent and untruthful. Nevertheless, Tsvangirai's call for violence is said to be against the inclusive government's national healing and reconciliation programme and is thus condemned by the writer of the article.

The MDC-T president, Mr. Tsvangirai, is reported (see example 2 in table 5) to have urged his party supporters to use violence in future elections. This call for violence follows claims by the MDC-T leader that their members were violently attacked by Zanu-PF in past elections and it is time for them to pay back. Example 3 in table 1 shows MDC-T's co-Home Affairs Minister Theresa Makoni justifying Mr. Tsvangirai's call for violence by claiming that it was high time they fought back. Consequently, a critical discourse analysis reveals an ideology, held by The Zimbabwe Herald Online, that the MDC-T party and all 
its participants are violent in nature as they always disrupt all the peace making efforts that the other parties in the inclusive government would have initiated by inciting violence in its supporters. In the foregrounded information in table $5 \mathrm{MDC}-\mathrm{T}$ is the only political party that is explicitly accused of inciting violence and not any other party. On the other hand, foregrounding is used on Zanu-PF and its participants when sending messages that condemn any form of violence (see table 6 below).

Table 6. Shows Foregrounding when Reporting on Zanu-PF and MDC-M Participants Condemning Election Violence

\begin{tabular}{||l|l||}
\hline \multicolumn{1}{|c|}{ Theme } & \multicolumn{1}{|c||}{ Rheme } \\
\hline $\begin{array}{l}\text { 4. Zanu-PF Politburo member Cde Tendai } \\
\text { Savanhu ... }\end{array}$ & ...expressed concern over the political violence. \\
\hline $\begin{array}{l}\text { 5. Zanu-PF Harare provincial spokesperson Mr. } \\
\text { Willias Madzimure... }\end{array}$ & $\begin{array}{l}\text {... yesterday said it was disturbing to note that } \\
\text { people were attacking each other. }\end{array}$ \\
\hline $\begin{array}{l}\text { 6. MDC-M deputy spokesperson Mr. Kurauone } \\
\text { Chihwayi... }\end{array}$ & $\begin{array}{l}\text {....said it was unfortunate that some leaders who } \\
\text { were signatories to the Global Political Agreement } \\
\text { were inciting violence. }\end{array}$ \\
\hline
\end{tabular}

As reflected in table 6 above, Zanu-PF and MDC-M, who happen to be the other two parties involved in the inclusive government with MDC-T, are represented as the only parties that seem to condemn political violence ahead of the forthcoming presidential election. Examples in table 6 show how the proper names Tendai Savanhu, Willias Madzimure and Kurauone Chihwayi, who condemn violence, are pre-modified by the cluster nouns Zanu-PF Politburo member, Zanu-PF Harare provincial spokesperson and the MDC-M deputy spokesperson respectively. All the three high profile titles are foregrounded so as to portray the act of political violence, castigated by members of the MDC-T party under strict instructions from Tsvangirai, as being condemned by authoritative people in the inclusive government. Zanu-PF and MDC-M are represented as the only two political parties in the inclusive government who share a common vision on the issue of a peaceful forthcoming presidential election, a vision which MDC-T is portrayed in The Zimbabwe Herald Online editorial articles as not to be part of.

\subsubsection{Are nominalizations used?}

Nominalization is another process that is predominant in editorial articles from The Zimbabwe Herald Online. Matthew (2007) defines nominalization as the use of a verb, adjective or adverb as the head of a noun phrase. In an editorial article, the leader of the MDC-T party is introduced by writer as: 


\section{Otto Tendayi Mponda}

'TROUBLED MDC-T leader Mr. Morgan Tsvangirai says his party will set up an independent commission of inquiry to investigate senior officials behind an orgy of violence witnessed during the run up to the party's congress.'

Table 7. Showing Nominalization of the Adjectives 'Troubled' and 'Seasoned'

\begin{tabular}{|l|l||}
\hline \multicolumn{1}{|c|}{ Theme } & \multicolumn{1}{c|}{ Rheme } \\
\hline $\begin{array}{l}\text { 1. TROUBLED MDC-T leader } \\
\text { Mr. Morgan Tsvangirai... }\end{array}$ & $\begin{array}{l}\text {. } \\
\text { inquiry to investigate senior officials behind an orgy of violence } \\
\text { witnessed during the run up to the party's congress.” }\end{array}$ \\
\hline $\begin{array}{l}\text { 2. Seasoned political analyst } \\
\text { Professor Jonathan Moyo... }\end{array}$ & $\ldots$ also said the call for violence by Mr. Tsvangirai was not new' \\
\hline $\begin{array}{l}\text { 3. Acclaimed political analyst } \\
\text { Mr Godwin Mureriwa... }\end{array}$ & $\begin{array}{l}\text {..believes Zanu-PF will romp to victory in next year's elections } \\
\text { and the thought of this reality has caused confusion in the } \\
\text { opposition. }\end{array}$ \\
\hline
\end{tabular}

Example 1 in Table 7 above shows the name 'Mr Tsvangirai' being pre-modified by the adjective 'TROUBLED' MDC-T leader. Introducing the MDC-T leader as 'troubled' in capital letters clearly reveals a biased stance in reporting on the part of The Zimbabwe Herald Online as this is meant to act as a negative tag. The manner of presentation seems calculated in order to discredit Tsvangirai of his status. A troubled man is usually a person who is marked by constant problems and lacks inner calm. Consequently, a CDA analysis establishes that portraying a bad image of Mr. Tsvangirai happens to be one of The Zimbabwe Herald Online's ideological traits. Another instance of nominalization is found in the use of the verb 'Seasoned'. The writer reports:

'Seasoned political analyst Professor Jonathan Moyo also said the call for violence by Mr. Tsvangirai was not new.'

Reference to Professor Jonathan Moyo as 'Seasoned', by the writer, is meant to qualify him as a credible and highly experienced political analyst. Professor Jonathan Moyo's views are justified because of his professor title, honorable as well as authoritative position in Zimbabwean politics. From a CDA perspective the professor's remark that it was not the first time for Mr. Tsvangirai to incite violence in his supporters, goes down well with the ideology of the newspaper whereby the MDC-T party is labeled a violence driven political party. Thus, a flashback of Mr. Tsvangirai's history of calling for violence, from a person like Professor Jonathan Moyo who is well versed with Zimbabwean politics, is meant to persuade the readers into believing that MDC-T is a violent party which is not to be voted for at all costs.

In the third example in table 7, nominalization occurs through the use of the adjective 'Acclaimed' to describe political analyst Mr. Gordon Mureriwa. The editor of the article 
describes Mr. Mureriwa as acclaimed in order to prove to the reader that Zanu-PF will definitely win the anticipated presidential election simply because knowledgeable and highly regarded people like Mr. Mureriwa have said so. Referring to pro-Zanu-PF political analysts, Professor Jonathan Moyo and Mr. Murerwa, who only preach of Zanu-PF's victory in the forthcoming presidential election, actually betrays the ideology that the newspaper is biased towards Zanu-PF in its reporting. According to example 3 in table 7, The Herald Online portrays Zanu-PF, through the quotation it uses, as a powerful party that is definitely not going to loose the forthcoming presidential election, a stance which puts the other two rival political parties in the losing category. Thus, nominalization is used in the articles analyzed to persuade readers into believing what they read by virtue of the political and social status of the informant. The use of nominalization in The Zimbabwe Herald Online confirms with the findings from Fairclough (2001) who reports on the use of multi-word compound noun nominalization in the Lancaster Guardian (1986) for ideological reasons.

\subsection{Are the pronouns we and you used and if so, how?}

The pronouns 'we and 'you' are used in articles from The Zimbabwe Herald Online which report on the events occurring ahead of Zimbabwe's anticipated presidential election. The collective pronouns are used as persuasive strategies in order to foster a collective vision and perception of Zanu-PF at the expense of all its rivals. Chapanga and Choto (2004:7) say that, “...collective pronouns are aimed at obliterating differences and depicting the society as homogenous". They mention that the collective pronouns are aimed at organizing thematic concerns such as freedom, security, unity, social and economic development. There are two types of collective pronouns, the inclusive pronoun we, which is inclusive of both the reader and the writer, and the exclusive pronoun we which refers to the writer and one or more others but does not include the readers. This article, is also concerned with the indefinite pronoun you which is also used by the writers of the articles as a persuasive strategy.

The sentence below shows the writer speaking on behalf of the reader and himself when he uses the collective pronoun 'we':

In Livingstone, we were told it was alleged violence by Zanu-PF but, as events have since shown in the run-up to MDC-T's third congress in Bulawayo and elsewhere, we all realize that violence is manifest in MDC-T.

As shown above, the collective pronoun 'we' is used to include readers in the category of people who now realize that violence is manifest in the MDC-T party. The reader is assumed to have also realized that it is not Zanu-PF that is a violent party as previously alleged but the MDC-T party instead. The ideology of the MDC-T party being a violence driven party is maintained as the reader is assumed to be anti-MDC-T too as reflected in 
the use of the inclusive third person pronoun 'we' as shown above. The collective voice behind the use of the collective pronoun helps the writer to persuade the reader into joining the band wagon of accepting the message in the article as common knowledge to all.

The exclusive 'we' is used by the writer of the article extracted below, which reads:

'We, The Herald were, however, reliably informed that Mr Tshabangu was dragged to the back door of the party's regalia shop at Harvest House where he was assaulted by MDC-T youths.'

The writer of the article above uses the exclusive pronoun 'We' to refer back to the publishing firm 'The Herald Online' that he/she reports for. As shown above the newspaper reports that it was reliably informed by an unnamed source that Mr. Tshabangu, who is the MDC-T Matabeleland North provincial chairperson, was beaten up by MDC-T youths during a meeting at their Harvest House headquarters because of opposing Mr. Tsvangirai's proposal to unconstitutionally bring back 15 members into the national executive. Not naming the source of their information is meant to protect the identity of their informants whom they fear might be victimized by members of the MDC-T party, a party represented by the newspaper as very violent. Referring to themselves as 'we' is meant to inform the reader that they are the only source of information to be trusted as the news they publish is directly delivered to them by very reliable anonymous informants. Thus, the newspaper provides vivid information of how the MDC-T youths dragged a senior member of their party to a back door of the party's regalia shop because of a misunderstanding he had had with the party president Mr. Tsvangirai. From a CDA perspective, the power struggles in the MDC-T party are represented as the chief causes of intra-party violence.

The indefinite pronoun 'you' is used in an article from The Herald Online, to persuade the reader to follow the writer's line of argument as shown below:

'One could hardly believe this is the same man who fled his family home in Strathaven to hide in the Royal Netherlands Embassy claiming he feared for his life during the 2008 presidential run-off campaign. Anyway, enough about the man and his warts. You should just ignore his drama.'

As shown above, the second person single pronoun 'You' is used by the writer to directly encourage the reader/s to ignore Tsvangirai's efforts as a politician. Mr. Tsvangirai is portrayed as not quite the brave person he claims to be as he is reported to always being in constant hiding fearing for his life whenever a presidential election arises. The writer influences the reader to have a negative attitude towards the MDC-T party leader and not to listen to what Tsvangirai says thereby betraying the ideology that The Herald newspaper has of discrediting Tsvangirai's political abilities by all means possible. It emerges that the arguments made by editors of The Zimbabwe Herald Online are not directed necessarily towards the need for democracy but rather at attacking Tsvangirai and his MDC-T party. The use of the inclusive and exclusive 'we' as well as the second person singular 'you' 
proved that editors of The Zimbabwe Herald Online use language as propaganda meant to cheapen the MDC-T party at the expense of Zanu-PF.

\subsection{How are (simple) sentences linked together?}

Editorial articles from The Zimbabwe Herald Online make use of endophoric reference, which includes the linguistic features anaphoric and cataphoric reference, in order link sentences together. Richard et.al (1992) anaphoric reference is whereby the same thing enters into the discourse for the second time in a text whilst cataphoric reference points at something that is mentioned latter in the text. The use of anaphoric reference as a cohesive feature is evident in the writer's use of the second person single pronoun 'He' to refer to Mr. Tsvangirai as shown below:

'He castigated Mr. Tsvangirai for always making irresponsible public utterances.

"You give him a microphone and a crowd and he will say the most irresponsible thing. He will not talk about land utilisation or paying of civil servants. He will not talk about defending our minerals or selling of our diamonds. He will not talk about anything constructive. He is Mr. Bad News." he said.'

As shown above, a political analyst, Professor Jonathan Moyo, is reported to have castigated Mr. Tsvangirai for inciting political violence in his supporters during his MDC-T rallies. The pronoun ' $\mathrm{He}$ ' is used to negatively refer back and forth to $\mathrm{Mr}$ Tsvangirai thereby making the article a compact piece of writing that maintains the same ideology of presenting Mr Tsvangirai as 'Mr Bad News'. The following table shows a systemic functional analysis of the three clauses in which make reference to Mr Tsvangirai through the use of the pronoun 'He'.

Table 8. Showing How the Pronoun 'He' Is Used as a Cohesive Feature

\begin{tabular}{|l|l|l|l|l|l||}
\hline He & will & not & talk & about & land utilization or paying civil servants. \\
\hline He & will & not & talk & about & $\begin{array}{l}\text { defending our minerals or selling our } \\
\text { diamonds. }\end{array}$ \\
\hline He & will & not & talk & about & anything constructive \\
\hline Pronoun & Finite & Negative marker & Predicator & Matter & Complement \\
\hline Nom.gp. & Verbal group & Prepositional phrase \\
\hline
\end{tabular}

The polarity of all the three clauses in table 8 is negative. The use of the nominal group 'He' in conjunction with the negated verbal group 'will not talk' shows how much focus is placed on the pertinent issues that Mr. Tsvangirai does not address. He is belittled in the minds of the readers. Mr. Tsvangirai is portrayed to be an individual who always says irresponsible things whenever he is given the platform to speak to a large audience. The MDC-T leader is seen as the kind of person who talks of unconstructive topics such as promoting political violence at the expense of dealing with more pressing issues such as 
land utilization, paying civil servants and defending the country's minerals and sovereignty, topics which are thought by the political analyst quoted in table 8 , to be at the centerfold of the Zanu-PF's manifesto. Nevertheless, the information in table 8 presupposes that Zanu-PF and MDC-M are the only parties that talk of constructive topics such as land utilization, paying civil servants and defending the country's minerals etcetera. From a CDA perspective, highlighting Mr. Tsvangirai's weaknesses back and forth in the editorial article is done to maintain a 'Mr. Bad News' ideological tag.

In a different article from The Zimbabwe Herald Online, the theme of MDC-T violence is carried over by the writer through the use of the second person pronoun 'he' as shown below:

'Mr Tsvangirai has failed in his current tour of provinces across Zimbabwe to unequivocally condemn violence.

He told supporters in Masvingo the MDC-T would fight their opponents in the next election.

In Chegutu last week, he said violence was an option in regime change.'

Through the use of the pronoun 'he' Mr. Tsvangirai is said to have preached violence in the provinces of Masvingo and Chegutu. Consequently, Mr. Tsvangirai is reported to have failed to condemn violence in his tour of provinces in Zimbabwe. The pronoun 'he' is used to cohesively carry forth Mr. Tsvangirai's endeavors in which he urges his supporters to use violence against Zanu-PF in the next presidential election. The call for violence follows incidents from the previous 2008 presidential election where it is claimed by Mr. Tsvangirai that members of the MDC-T party were beaten defenseless by both the Zanu-PF led police and army. The Zimbabwean Herald Online reports that Mr. Tsvangirai said that violence was an option if a regime change was to take place in Zimbabwe. From a CDA perspective, the MDC-T party is portrayed as a party that intends to take over power from the current Zanu-PF president by any means. Thus, an ideology of the MDC-T party being a terroristic party is observed when it is reported to have considered opting to use violence to unconstitutionally obtain presidential power from Zanu-PF.

Anaphoric reference is used by the writer to refer back to Professor Moyo as shown in the use of the words 'Professor Moyo said' at the end of the sentences below:

" "Since that time the MDC-T has shown its true colours of violence not only against Zanu-PF but even within itself leading to the 2005 split." Prof Moyo said.

He said a culture of violence within MDC-T was evident in the run-up to its April Bulawayo congress.

"In all these instances, nothing has been done to curb violence within the MDC-T." Prof Moyo said.'

As shown in the above example, Professor Jonathan Moyo's name is placed at the end of his quotation to remind the reader that the words were uttered by a Professor. The ideology 
of 'a violent MDC-T party' is substantiated by quotations from Professor Jonathan Moyo who is highly regarded by the editors of The Herald Online as he constantly brands the MDC-T party as a violence driven party. Mentioning the name of the professor at the end of the sentences is also used for cohesive purposes as well as to authenticate the information written. The MDC-T party is reported by Professor Moyo as not only practicing its violent culture on Zanu-PF members but on its own supporters as well which is reported to have been the reason for its split in 2005. The MDC-T party is also reported by Professor Moyo as having been violent in the run-up to its April Bulawayo congress. In the end statement, Professor Moyo concludes by saying that the MDC-T party never did anything to curb violence within its party in all instances, which suggests that the MDC-T party is a party that promotes violence.

Cataphoric reference, which points at something that is mentioned latter in the text, is used by the writer to show Zanu-PF's disapproval of MDC-T's violent nature:

'However, Zanu-PF yesterday condemned the cruelty behind MDC-T leadership's call for violence and urged its supporters to be peaceful in the face of open hostility from a partner in the inclusive Government.

"This is unacceptable. As Zanu-PF, we do not subscribe to violence and we do not encourage our people to engage in violence. We want peace and stability in the country and we are totally opposed to violence, " said party spokesman Cde Rugare Gumbo.'

Cataphoric reference is used to cohesively elaborate arguments as shown by presenting the name Cde Rugare Gumbo, for the first time, at the end of his quotation. The cohesive feature is effectively used by the writer to provide the reader with a well structured argument which ends with Zanu-PF condemning MDC-T acts of violence. The writers of the articles from The Zimbabwe Herald Online report on MDC-T's violent escapades, first, and then through the use of cohesive features provide Zanu-PF'S anti-violence condemnations afterwards, thereby, revealing a biased trait towards Zanu-PF. The findings reveal the tactful use of words by writers as weapons to entice and persuade readers to support their views. The findings also confirm the assumption that every linguistic usage encodes ideological positions (Fairclough, 2001).

\section{Conclusion}

The major finding of this study is that editors of The Zimbabwe Herald Online newspaper have a negative hype towards the MDC-T party as compared to the other MDC-M party ahead of the forthcoming Zimbabwean presidential election. The study revealed that the newspaper's editors have a bias towards Zanu-PF despite their claim of being neutral, in their reporting, so as to honor the current inclusive government. The MDC-T party is portrayed as no threat to Zanu-PF's victory in the next presidential 
election despite the outcome of the 2008 presidential election whose results led to a deadlock between Zanu-PF and the MDC-T party. It was the 2008 deadlock in presidential election results that led to a two year Global Political Agreement between Zanu-PF, MDC-T and MDC-M parties, which lapsed in 2011.

As part of the newspaper's propaganda the MDC-T party is negatively tagged to various atrocities ranging from intimidation to killings among others. The MDC-T party is represented as a party that is fuelled by violence. MDC-T violence is a dominant theme in articles from The Zimbabwe Herald Online newspaper as evidenced in their calculated use of both vocabulary and grammatical features to represent the MDC-T party as being agents of both interparty and intraparty violence. The vocabulary features identified in the data analyzed revealed that words were ideologically contested in order to provide biased contrastive comparisons between Zanu-PF and the MDC-T party. Metaphors were also used to compare the MDC-T party to terrorist movements such as the late Bin Laden's Al-Qaeda. The use of other semantic features such as expressive meaning, to represent the MDC-T party as violent betrays The Zimbabwe Herald Online's ideological practices.

The MDC-T party is also portrayed as a puppet to western super-power states such as the United Kingdom and the United States of America. Portraying the MDC-T party as a puppet political party is meant to discredit its commitment to protecting the sovereignty of Zimbabwe, a quality which is constantly tagged to Zanu-PF. The editors of the Herald make use of direct quotations that show Tsvangirai and other MDC-T officials inciting violence in their supporters whilst those from Zanu-PF officials are always positive. The linguistic features used in the direct quotations chosen for publication reveal on-going struggles of power between Zanu-PF and the MDC-T party. Thus, The Zimbabwe Herald Online acts as a battle ground for bitter words between the two rival parties including the MDC-T party, which is portrayed supporting Zanu-PF in most cases.

Grammatical features such as foregrounding and nominalization among others were used as persuasive strategies meant to convince the reader into believing that the MDC-T party was not a party to vote for in the forthcoming presidential election as it is did not have the interests of the civil servants and the people of Zimbabwe at heart. Cohesive devices such as anaphoric and cataphoric reference were used in order to refer back and forth to particular individuals so as to emphasize certain ideologies. Semantic features such as words with expressive and propositional meanings also revealed hidden biases amongst The Herald Online editors. The findings from this current study are inline with those from a study carried out by Ndlovhu in 2006. Ndlovhu (2006) carried out a critical discourse analysis of articles from The Zimbabwean Herald print newspaper reporting on Zanu-PF's fast-track Land Reform Programme that had begun in the year 2000. The findings revealed that the editorial articles from The Zimbabwean Herald print newspaper made use of 
discourse control and semantic twists that were always in support of, the then solely ruling, Zanu-PF's fast-track land reform programme. Ndlovhu's (2006) findings are pertinent to this current study as they reveal how the language used by the Zimbabwean media reveals dominant ideologies and biases. The current editors of The Zimbabwe Herald Online share the same principles as those who edited the columns of The Zimbabwean Herald print newspaper that Ndlovhu (2006) analyzed for his 2006 publication.

\section{References}

Baker, M. 1992. In other words: A coursebook on translation [M]. London: Routeledge.

Bangura, Y. 2002. United Nations Research Institute for Development. Ethnic Structure, Inequality and Governance of the public sector [R]. UK: Basingstoke.

Chapanga, E. and Choto, C. 2005. Coercive Discourse Patterns in President George Bush's 2001 and 2005 Inaugural Addresses [J]. Zambezia, 32(1):1-17.

Eggins, S. 1994. An Introduction to Systemic Functional Linguistics [M]. London: Pinter.

Fairclough, N. 1989. Language and Power [M]. London: Longman.

Fairclough, N. 2001. Language and Power [M]. Second Edition. London: Longman.

Hakemulder, J. 2004. Foregrounding and its effects on readers' perception [J]. Discourse processes, 38(2):193-218.

Halliday, M.A. K. and Mathiessen, C. 2004. An Introduction to Functional Grammar [M]. 3 rd edition. Great Britain: Hodder Education.

Kroeger, P. 2005. Analyzing Grammar: An Introduction [M]. Cambridge: Cambridge University Press.

Ndlovhu, F. 2006. Rethinking the language of politics in 21st century Zimbabwe: A critical discourse analysis [J]. A Journal of Contemporary Research, 3(1):223-235.

Potts, C. 2003. The Logic of Conventional Implicatures [M]. University of California at Santa Cruz doctoral dissertation.

Richards, J. C., Platt, J., Platt, H. 1992. Longman dictionary of language teaching applied linguistics [M]. Harlow, Essex: Longman.

\section{Fairclough's questions}

1. What experiential values do words have?

What classification schemes are drawn upon?

Are there words which are ideologically contested?

Is there rewording or overwording?

What ideologically significant meaning relations are there between words?

2. What relational values do words have?

Are there euphemistic expressions?

Are there markedly formal or informal words?

3. What expressive values do words have?

4. What metaphors are used?

5. What experiential values do grammatical features have?

What types of process and participants predominate?

Is agency unclear?

Are processes what they seem?

Are normalizations used? 


\section{Otto Tendayi Mponda}

Are sentences active or passive?

Are sentences positive or negative?

6. What relational values do grammatical features have?

What modes are used?

Are there important features of relational modality?

Are the pronouns we and you used and if so, how?

7. What expressive values do grammatical features have?

Are there important features of expressive modality?

8. How are (simple) sentences linked together?

What logical connectors are used?

Are complex sentences characterized by coordination or/ subordination?

What means are used for referring inside and outside the text? 